\title{
The Social Distance in Student-Lecturer Relation
}

\author{
M Fitria'; Koentjoro ${ }^{2}$ \\ Fakultas Psikologi, Universitas Gadjah Mada Yogyakarta \\ 르aya.fitria@mail.ugm.ac.id; ${ }^{2}$ koentjoro@ugm.ac.id
}

\begin{abstract}
This study aims to look at the form and ethics of relations as what happened and expected by lecturers and students. The context of this study is students majoring in psychology. The most important reason is because psychology closely related to human and the practical profession is dominantly characterized by direct interaction with fellow human. Lecturers are indeed just one object of student interaction on campus, in addition to friends and other academics on campus. The ethics of lecturer-student relations in general are still assumed as teacher-student relations where students are in a subordinate position. This study used interviews, FGDs, and questionnaires in extracting data. The result show that the experience of student and lecturer relations occurs more complex which ultimately results in several patterns of relations at once. The researcher uses Fiske's theory which identifies the basic forms of social behavior, namely communal sharing, market pricing, equality matching, and authority ranking. The four forms of relations are experienced simultaneously by students and lecturers.
\end{abstract}

Keywords: Student-Lecturer Relation; Social Distance; Relation

\section{INTRODUCTION}

Relationship between a teacher and a student was generally described as formalized interpersonal association between an authority figure and a subordinate who interact in certain situation and time [1][2]. The investigation of student-teacher in higher-education is important to be extended for at least three reasons: First, many universities worldwide have large number of student drop-out, with high human and financial costs. The resesearch about TSR is relevant to reduce this unwanted trend. Secondly, the need to belong also affects university teachers as a positive 'relational classroom environment', including positive interactions and relationships, might give positive consequences on the teachers themselves (e.g., on teachers' positive emotions). Thirdly, relation-based teaching and learning process has been ascribed as excelence's indicator for a good and qualified university[3][4].

Indonesian society is quite acknowledged to have a high power distance which indicating a high level of inequality of power and wealth within the people as well as high uncertainty avoidance index, positioning a low level of tolerance for uncertainty and ambiguity[5]. Those two can bring inequalities of power and wealth to grow within society, when strict rules, regulations, policies and controls have been ruled to decrease the amount of uncertainty. In contrast, Indonesia has a very low index regarding individualism, that is a collectivist country according to Hofstede's. In a collective society, interpersonal closeness, substantial contact among individuals is clearly valueable. The classroom is considered to be a sample for a social unit within the society. Teacher-student relationships are also descriptions 
for Indonesian society culture, which are influenced by pervasive cultural values, including power distance such as paternalism and respect for older individuals, implicitly regulating interactions between the young and the old. Order and neatness are managed by the elders and the younger generation should obey the rules[5].

On the other hand, higher education is recently considered as bussiness-like enterprise, where the students are seen as customers who seek a satisfying business-like relationship. Teachers and lecturers are more likely the producers that deliver knowledge, skills and competencies he or she needs and wants [6]. This kind of trend also interfere in many collectivist countries. The more egalitarian sense in relationship should be enhanced. Moreover, in some formal academic process, students seem to have a more higher level position. Universities are highly recommended to embrace the culture of academic staff evaluations by students at the end of every teaching-learning session which also used as the reports for personnel decision making such as promotions, retention and salary increases for staff. This could make lecturers become more committed to their task and institution. On the other hand, this actually has confronted the nature of interaction and relationship in collectivist culture. It can be conflicting for the student-lecturer relationship.

\section{RESEARCH METHOD}

This study aims to look at the form and ethics of relations as what happened and expected in the relation between lecturers and students. The context of this study is students majoring in psychology. The most important reason is because psychology closely related to human and the practical profession is dominantly characterized by direct interaction with fellow human. Lecturers are indeed just one object of student interaction on campus, in addition to friends and other academics on campus. The qualitative descriptions using content analysis given in this report are based on data from interviews (lecturers:11; students:10), FGDs (lecturer: 2; student:2), and questionairs (lecturers: 24; student: 95). Data from student and lecturer were compared in order to help understand the perception the students hold of their relationship with lecturers and vice versa.

\section{RESULT AND DISCUSSION}

The result shows that the experience of student and lecturer relations occurs more complex which ultimately results in several patterns of relations at once. First pattern, according to both lecturers and students ilustrates that lecturers have and have to have higher level positition than students. The quotations are the following.

"Harusnya dosen itu orang tua kita di kampus. Tidak ada batasan tapi harus ada etika."(student)

("The lecturers should be like our parents on campus. There are no restrictions but there must be ethics.")

"Dosen memiliki derajat yang lebih tinggi. Dosen pencatat amal mahasiswa di kampus." (student)

("Lecturers have higher degrees. Lecturers are recording student behavior in campus.")

"Dosen itu layaknya orang tua, ada semacam etika dalam menghormati orang tua" (lecturer)

("Lecturers are like parents, there is a kind of ethics in respecting parents") 
"Sopan santun mahasiswa perlu ditingkatkan" (lecturer)

("The courtesy of students needs to be improved")

"(kapan relasi dengan mahasiswa terasa tidak menyenangkan?) ketika mahasiswa tidak sopan"(lecturer)

"(When is the relationship with students uncomfortable?) When students are not polite")

The following quotations reflect the more egalitarian form of student-lecturer relation.

"Dosen bersikap maha benar, harusnya yang friendly biar mahasiswa lebih nyaman diskusi. Friendly tapi tetap tegas." (student)

("Lecturers are always right, they should be friendly so students can be more comfortable in discussion. Friendly but still firm.")

"Dosen fasilitator di kampus. Kita baca buku juga, jangan hanya manut dengan dosen."(student)

("Lecturers are facilitators in campus. We read books too, so don't just be obedient to lecturers.")

"Membangun relasi dengan dosen dirasa perlu, karena sebagai mahasiswa aktif kita masih berhubungan dg dosen dan memerlukan beliau sebagai teman bertukar pikiran" (student)

("Building relationships with lecturers is necessary, as an active students we are still in contact with lecturers and need him/her as a friend to exchange ideas")

"Mahasiswa adalah mitra utama dalam pengajaran di perguruan tinggi"(lecturer)

("Students are the main partners in teaching in universities")

"Karena relasi yg baik akan sangat membantu dalam proses pembelajaran"(lecturer)

("Good relationship will be very helpful in the learning process")

"Relasi (dengan mahasiswa) perlu, untuk saling bekerja sama dalam bertukar pengetahuan, pengalaman, dan di masa dpn utk networking."(lecturer)

Next quotations are indicating the student-lecturer relations which considering high profesionality in their student-lecturer relation which has clear boundaries.

"Relasi dengan mahasiswa masih sebatas tugas tri dharma saja."(lecturer)

("Relationships with students are still limited to tri dharma assignments.")

"Hubungan dengan dosen itu cukup formalitas saja. Dosen ngajar, mahasiswa belajar." (student)

"The relationship with the lecturer is quite a formality. Lecturers teach, students learn”.) 
"Dosen tidak harus mengayomi kayak guru murid, tapi harusnya profesional, kalau ada mahasiswa itu mbok ya didengerin. Jangan ketus."(student)

"Lecturers do not have to protect like a student teacher, but they should be professional, if there are students, they will be listened to. Don't be rude. "

"Dosen-dosen di sini memiliki wajah yang dingin, terasa tersindir, membuat saya kurang nyaman." (student)

"The lecturers here have cold faces, are insinuated, making me uncomfortable."

"Hubungan penting, tapi sebatas hubungan profesional saja. Saya malah ndak pengen deket sama dosen. Pengen bebas."(student)

"Relationships are important, but limited to professional relationships. I don't even want to be close to the lecturer. Just want to be free.)

"Kalau terlalu kenal, gak bisa titip absen." (student)

("If you are too acquainted, you cannot leave.")

Fiske's theory identifies the basic forms of social behavior, namely communal sharing, market pricing, equality matching, and authority ranking. The motivation, planning, production, comprehension, coordination, and evaluation of human social life are lirgely depend on combinations of those 4 psychological models [7][8]. The four forms of relations are experienced simultaneously by students and lecturers.

In communal sharing, people within this category are treated equivalently. They will see them selves as equal and want to be treated equally. Being the same and in the parallel track have practically been internalized by both student and lecturer as if they are all partners working as a team, in teaching and learning, and also in research collaboration.

In authority ranking, people are seen to be asymetrical and linearly ordered along hierarchical social dimension. Some people are considered above and others below. People higher in rank have prestige, prerogatives, and privileges that their subordinates lack, but they are obliged morally to their inferiors protection and pastoral care. Authorities also have control of some aspects of their subordinates' actions. Both student and lecturer realize this position clearly and unarguably.

In equality matching, people keep track of the imbalances among them. Some student feels that they have their own position in some point who can be imbalances for lecturer if they do not keep their own position. In market pricing logic, people attend to ratios and rates. Cost-benefit ratios are the preminent factors. Even though only a few student statement reflects this relational type, but the trend of it is quite predictable. The tuition fees in many educational institutios are predominantly increasing. Parents and student probably will start calculating how much they give and get. As stated before, education is recently considered as bussiness-like enterprise, where the students are seen as customers who seek a satisfying business-like relationship.

Even though the result shows there are indicators that lead to four model of relationship by Fiske, but a good student-lecturer relationship is generally seen as closer kind of relation which narrow the distance between student and lecturer. These data categories are reflecting deminishing social distance between them. Good student-lecturer relationship are: 
Relations that are informal (close, outside the classroom relations are not far away, can be parents or story friends for students, students do not feel afraid or reticent, lecturers can position as friends who can chat and joke)

$\square$ Flexible (can put themselves as teachers and friends, parents or friends, lecturers understand the state of students, lecturers give time outside of class)

$\square$ Two-way relations (reciprocal) (Lecturers are willing to accept students' opinions even though their opinions are incorrect and can later be corrected by the lecturer, open)

$\square$ Objective (may not be subjective)

$\square$ Mutual respect and respect (must be close must still pay attention to the way of communication, students can also follow the wishes of lecturers, mutual respect and respect)

Based on this study, the relation of students 'lecturers from students' perceptions is: a relationship that occurs between lecturers and students that is informal, flexible, reciprocal, objective and respects each other. In other study, some university lecturers defined a good relationship with students using adjectives such as honest, respectful, trusworthy, safe, fair, encouraging, caring, open, comfortable, safe, enjoyable and supportive.[4][9][10]

Ang stated that dependency in student-teacher relationship applied to research on younger students (e.g., kindergarten and primary school). Higher level student have lower the influence of dependency in their student-teacher relation [11]. Research about student and teacher in higher level education have eliminated the dimension of dependency in the operationalitation of the relationship [12]. However, the level of indepency still depends on the teaching context [13].

Gholami and Tirri defined mutual respect as 'respectul didactics', and it is part of a multi-dimensional construct of 'care' in school teaching which related to nurturing 'students' character.[14] It is related to the concept of 'caring behavior' within studen-teacher relationship in higher education. That is characterized as an adult-adult relationship. [15] 'Care' is such an instrinsic motivation that a very important vactior in student learning. [9]

\section{REFERENCES}

[1] Bartlett, "Dialogue, Knowledge, and Teacher-Student Relations: Freirean Pedagogy in Theory and Practice," Comp. Educ. Rev., vol. 49, no. 3, p. 344, 2005.

[2] M. D. Camp, "The power of teacher-student relationships in determining student success," ProQuest Diss. Theses, p. n/a, 2011.

[3] G. Hagenauer and S. Volet, “'I don't think I could, you know, just teach without any emotion': Exploring the nature and origin of university teachers' emotions," Res. Pap. Educ., vol. 29, no. 2, pp. 240-262, 2014.

[4] G. Hagenauer and S. E. Volet, "Teacher-student relationship at university: an important yet under-researched field," Oxford Rev. Educ., vol. 40, no. 3, pp. 370-388, 2014.

[5] R. Maulana, M. C. Opdenakker, P. den Brok, and R. Bosker, "Teacher-student interpersonal relationships in Indonesia: Profiles and importance to student motivation," Asia Pacific J. Educ., vol. 31, no. 1, pp. 33-49, 2011.

[6] M. C. Chepchieng and S. N. Mbugua, "University students' perception of lecturerstudent relationships: a comparative study of public and private universities in Kenya," Acad. J. Res. Rev., vol. 1, no. June, pp. 80-84, 2006.

[7] A. P. Fiske, "The four elementary forms of sociality: Framework for a unified theory of social relations," Psychol. Rev., vol. 99, no. 4, pp. 689-723, 1992.

[8] A. P. Fiske, "Horizon Metarelational models: Con fi gurations of social 
relationships," vol. 18, no. May 2011, pp. 2-18, 2012.

[9] M. Komarraju, S. Musulkin, and G. Bhattacharya, "Role of Student-Faculty Interactions in Developing College Students' Academic Self-Concept, Motivation, and Achievement," J. Coll. Stud. Dev., vol. 51, no. 3, pp. 332-342, 2010.

[10] A. Jacklin and P. le Riche, "Reconceptualising student support: From 'support' to 'supportive,"' Stud. High. Educ., vol. 34, no. 7, pp. 735-749, 2009.

[11] Wan Har Chong, V. S. Huan, Choon Lang Quek, Lay See Yeo, and R. P. Ang, "Teacher-Student Relationship: The Influence of Teacher Interpersonal Behaviours and Perceived Beliefs about Teachers on the School Adjustment of Low Achieving Students in Asian Middle Schools," Sch. Psychol. Int., vol. 31, no. 3, pp. 312-328, Jun. 2010.

[12] R. Ang, "Development and validation of the teacher-student relationship inventory using exploratory and confirmatory factor analysis," J. Exp. Educ., vol. 74, no. 1, pp. 55-73, 2005.

[13] S. Lindblom-Ylänne, K. Trigwell, A. Nevgi, and P. Ashwin, "How approaches to teaching are affected by discipline and teaching context," Stud. High. Educ., vol. 31, no. 3, pp. 285-298, 2006.

[14] K. Gholami and K. Tirri, "Caring Teaching as a Moral Practice: An Exploratory Study on Perceived Dimensions of Caring Teaching," Educ. Res. Int., vol. 2012, pp. 1-8, 2012.

[15] M. D. Halx, "Re-conceptualizing college and university teaching through the lens of adult education: Regarding undergraduates as adults," Teach. High. Educ., vol. 15, no. 5, pp. 519-530, 2010. 